\title{
LTBR wt Allele
}

National Cancer Institute

\section{Source}

National Cancer Institute. LTBR wt Allele. NCI Thesaurus. Code C116041.

Human LTBR wild-type allele is located in the vicinity of $12 \mathrm{p} 13$ and is approximately $17 \mathrm{~kb}$ in length. This allele, which encodes tumor necrosis factor receptor superfamily member 3 protein, is involved in lymphotoxin-mediated signaling. 